\title{
Impact of Information and Communication Technology (ICT) Investment on different Components of Human Development in Developing Countries
}

\author{
ZAHEER UDDIN FAROOQI \\ PhD Scholar. Department of Economics, \\ Government College University Faisalabad Pakistan. \\ Email: zaheerf85@gmail.com
}

\author{
MUHAMMAD SOHAIL AMJAD MAKHDUM \\ Assistant Professor. Department of Economics, \\ Government College University Faisalabad Pakistan. \\ Email: sohailmakhdum@hotmail.com
}

\section{MUHAMMAD RIZWAN YASEEN}

Assistant Professor. Department of Economics, Government College University Faisalabad Pakistan.

Email: rizwany2001@yahoo.com

\begin{abstract}
ICT investment is the key factor of human development in developing countries. Human development has three main components such as GDP, health and education. The current study explores the impact of ICT investment on the components of human development in 67 selected developing countries. Selected developing countries are divided into four panels on the basis of income as lower, lower middle, upper middle and high income countries. Data were collected from World Bank, ITU and Word Information Technology and Services Alliances website for the period of 2000 to 2018. Pesaran, Friedman and Frees CSD tests confirmed the presence of cross-sectional dependency in the variables and consequently, CIPS second generation unit root test were used for stationarity. Kao and Pedroni test and ARDL model were employed to check the long-run cointegration and regression analysis respectively. The regression results showed the mixed findings in different panels. The results explored that ICT investment have different impacts on the components of human development in four panels of the developing countries. Communication investment, software and hardware investment have positive impact on the components of human development in all panels. It is recommended that government should focus on ICT investment to increase GDP, level of education index, life expectancy index and HDI.
\end{abstract}

Keywords: ICT Investment, Human Development, Developing Countries, Panel Data.

\section{Introduction}

Information and Communication Technology (ICT) is comprises of software, hardware, networks, collection, storage and transfer of information. It also increases the rate of human capital accumulation as it has access to existing knowledge and information (Goschin \& Constantin, 2007). ICT related devices included computer hardware and software, access to internet, radio, television, video and digital cameras etc. ICT has the ability to cover the long distance with relatively low cost (Goschin \& Constantin, 2007) by using these equipments in different fields (Ahmed, 2010). ICT is a central part of modern era. People can 
talk, text and tweet on mobile or entertain themselves by Internet surfing (Van et al., 2011). Apart from individual use, it also affects the people's lifestyle and economy. ICT usage is helpful to increased flow of information and knowledge in the world by reducing the transaction cost and uncertainties in the economic activities (Chen \& Dahlman, 2005). ICT eliminates the barriers in the transfer of information and augments factors through coordination and automation. It also increases the efficiency of working, inclusiveness and innovation of new technology in knowledge based economies. ICT is used to improve the level of socioeconomic development (Majeed \& Ayub, 2018). It improves the efficiency of services and operations at both, organizational and country levels. In industrial economies, ICT serves as an important factor of economic growth. ICT is the main source of technological advancement in the modern economy (Jelassi, 2009) and provides many types of services like, applications regarding education and management systems and new technologies such as cellular phones, using software. The issue of transparency and accountability is also being managed by using ICT (Martínez-Frías, 2003).

Many devices like computer, hardware, software, radio, television, cellular phones, network, \& satellite systems come under the umbrella of ICT. Many applications and services are associated with these ICT such as online jobs, online education, video conferencing, online health and transport services. In the last fifty years, ICT impact on economic growth has gradually increased all over the world. Nobel Prize holder Solow said before 25 years ago that, "People can see the computers everywhere in all sphere of life". ICT is enhancing impact on economic development and human development. ICT is considered a knowledge base technology; it can be adopted to many applications. ICT play a significant role in production and consumption sectors (van Ark et al., 2011). ICT related devices such as telephone, cell phone, computer and internet are the essential parts of modern life in all over the world. ICT increased access to information and knowledge, connects people, improve the trade of goods and services across the globe. ICT is a key factor for sustainable development (Baliamoune-Lutz, 2003).

Investment in ICT sector is the spending for communication, hardware, software and services in a country (Ahmed, 2006). Investment for software means total spending on different software packages. Hardware investment means spending on equipment related to ICT. Services investment refers to investment on software customization, R\&D and IT related miscellaneous. Communication investment means spending on fixed and wireless communication system (Bankole et al., 2011). Since the late 1980s, some world level institutions such as World Bank, United Nation, IMF and ITU have been advocating that increased the investments in ICT sector for developing countries. Investment in ICT and economic development has positive correlation in developing countries. The evidence shows that output of ICT Investment in the developing countries is not same as in the developed world (Ngwenyama et al., 2006). ICT sector is the key driver of economic and human productivity (Strauss \& Samkharadze, 2011). ICT investment in the field of software and hardware equipment is main factor of development. It depends on level and classification of economies (Erumban \& Das, 2016). ICT investment and human development is different in low income economies as compared to high income economies due to many reasons. Developing economies have many deficiencies such as limited financial resources, unskilled human capital, lack of skills knowledge \& computer literacy rate and low knowledge about the benefits of ICT (Niebel, 2018).

ICT is the key factor of human development in the developing economies (Cortés \& Navarro, 2011). Human Development Index (HDI) is consists of three components such as living standard, health and education. Living Standard is determined by GDP per capita, knowledge acquisition is determined by literacy rate or education index, health longevity is measured by life expectancy index (Neumayer, 2012). According to International organizations like ITU, WB and IMF, ICT has great potential for socioeconomic development in developing economies (Bankole et al., 2011).

In the modern era, ICT is being penetrated into all fields of human development (HD) activities at record rate. In the Information age the distribution of ideas for the human development is power of world economy (Castells, 2000). The use of mobile phone and Internet is helpful to implements international law and protect human rights (Greig et al., 2002). 
ICT is the most powerful force in order to achieve the targets of social and economic developments in the developing world. ICT has strong impact on HD. The main purpose of HD is to broaden choices of people that leads to access of knowledge (Ul Haq, 1995). ICT is powerful source of information which is highly beneficial and influential for human development (Lee, 2001). ICT plays an essential role in medicine field for service delivery and knowledge management. ICT has crucial role in the improvement of health outcomes. It can save lives by sharing information regarding health care medicine. ICT is also contributing to enhance the way of learning in the developing world. ICT is also used as a tool in reforming the education systems, access to educational resources, improving the management of education and enhancing academic techniques (Kuyoro et al., 2012).

ICT is used to communicate the people to enhance the standard of living. The knowledge has great value for human development. ICT is a channel used to spread the knowledge among the people. Human development has three essential choices such as acquire knowledge, long and healthy life and enhance the standard of living (Programme, 2003). HDI is an indicator which is used to measure the level of human development of a country (Bankole et al., 2011). The main objective of the current study is to explore the impact of ICT investment on the different components of human development in developing countries.

\section{Theoretical Background}

The concept of development is versatile and it mainly focused on standard of living of the people and national income of the country. The concept of development was extended during the late 1980s and social factors were included in development process. According to the David (2002) "National income level is not only address the progress of the country. Economic growth enhance human development, education and health is beneficial for each other (Fielding, 2002). Development is not only measured by GDP, social factors such as education and health is also improving the economic success of a country. The researchers has explore that, there are strong correlation among the economic growth, education, health and political development (Ngwenyama et al., 2006). It is explore in human development report published in 1990that, factors of human wellbeing such as education, health and democracy are important determinant of the development. In 1990, new HDI was introduced. The purpose of the HDI is to estimate the achievement of the country on the basis of three components of human development such as standard of living, knowledge and longevity (Bhanojirao, 1991).

ICT has the productive capacity for the development of nation, it provide access to knowledge, skill, health resources and global market (Y. Chen \& Zhu, 2004);(Crafts, 2003). Since the 1980, some institutions like, United Nation (UN), IMF, WB and ITU have been emphasized to increase the investment in ICT sector for developing countries. In 1997 a report was published by United Nation Commission on Science and Technology, according to this report, ICT is the important factor of development of a country. Previous studies shows that, investment in ICTs and economic development has positive correlation in developed nations but in developing countries is not wide (Jalava \& Pohjola, 2002) ; (Kenney, 1995) ;(Kenny, 2000). The research regarding ICT investment in developing countries is still limited (Ngwenyama et al., 2006). So there is enormous need for further research in this area.

ICT has main four areas of investment such as communication, software, hardware and internal spending. These areas are possessed different types of knowledge. Hardware is skill knowledge which is used for operating \& controlling software. Knowledge regarding software is used for analysis, modeling, and in business processing. Knowledge about the software is more efficient, it facilitate the people to perform their work efficiently and in easy ways (Armour, 2000). Internal spending is very important in ICT field. It is used as bridge between software and hardware knowledge. ICT related investment has positive effect on performance and development of the country (Kim et al., 2008). 


\section{Importance of the Study}

Many previous studies used the only HDI or one component of HDI such as standard of living as a dependent variable against the ICT investment but in the current study we used three components of HDI and also including HDI as dependent variable which is not seen before (Kim et al., 2008); (Bankole et al., 2011).New methodology are used to explore the relationship between ICT investment and components of HDI such as Friedman's CSD, Pesaran's CSD and Frees's CSD tests are used for checking cross-sectional dependency among variable. CIPS second generation unit root test is used to check the stationarity of the data. Kao test is used for cointegration. New controlled variable are used with ICT related investment variable. Developing countries have less investment in ICT sector as compared with developed world. Therefore, in developing countries, ICT investment decreased over the years. Developing countries have lack of complimentary requirements for ICT, lower absorptive capacity and lack of investment in human capital and R\&D (Hashem, 2015).

\section{Review of the Literature}

Hashem (2015) estimated the relationship between ICT investment and human development. Different component of ICT investment on different dimensions of human development as well as education and standard of living are observed in the study. Results showed that ICT investment on different sectors have positive effect on human development. By gaining the human development, the economic growth in the country may also boost up. For factors like living standard of people and education and health ICT gives positive result.

Niebel (2018) examined the impact of ICT investment on economic growth in developing, emerging and developed countries. Data from 59 countries with the range of 1995 to 2010 are used for study. Result indicate that ICT having positive impact on economic growth in developing countries. Cortés \& Navarro (2011) studied the influence of ICT on human development and economic growth with selected 27 countries of European Union. Study explained the ICT adoption has achieved different levels human development. Study showed that ICT have a substantial impact on human development in selected countries.

Morawczynski \& Ngwenyama (2007) investigated the relationship between ICT investment and components of HDI such as education and health index in five western African countries by using Multivariate adaptive regression analysis. It found the significant relation between the ICT investment and HDI. Kim et al., (2008) studied the impact of software, hardware and internal spending investment on economic development in 51 developing countries. The results explore that ICT investment enhance the GDP of the countries.

Bankole et al., (2011) studied effect of ICT related investments on hardware, software, services and telecommunication investment on human development. It is found that the impact of ICT investment on human development is different in low, middle and high income economies. Kozma (2005)studied that ICT investment has positive impact on education and literacy rate. It increase the students' knowledge, skill and attitude. (Aristovnik, 2012) studied the efficiency and impact of ICT on educational outcome in selected European Union and OECD countries. It is found that ICT is very helpful to improve the educational level and quality of learning.

Chetley et al., (2006) studied the use of ICTs investment in health sector in developing countries. Study explore that ICT investment improve the health sectors in different ways. ICT improve the health care delivery units, it helps in sharing of knowledge regarding health issues such as diagnosis of diseases and mapping of public health threat. It makes easy flow of the information between the health works and general public. 


\section{Material and Method}

\section{Data and Descriptive Analysis}

Data of 67selected developing countries for the period of 2000 to 2018 are collected from World Bank (WB), International Telecommunication Union (ITU) and World Information Technology and Services Alliance (WITSA) websites. Selected developing countries were categories into four panels on the basis of income according to WB criteria; such as lower, lower middle, upper middle and high income countries. 14 countries were selected from lower income economies, 20 were selected from lower middle, 23 from upper middle and 10 were selected from high income economies. The name of the countries of above said four panels are mentioned at appendix (list of countries). Table.1 shows the descriptive statistics of four panels. The descriptive statistics shows the difference among the panels. During collection of data, we have faced the issue of missing data. To resolve this issue, we adopted two approaches, by taking the average of previous two values and extrapolate the missing data in Stata.

Table 1: Descriptive analysis

\begin{tabular}{|c|c|c|c|c|}
\hline Panels & Mean. & Min. & Max. & Std.Dev. \\
\hline \multicolumn{5}{|c|}{ GDP (Current US\$) } \\
\hline Low income Countries & 557.3370 & 111.9272 & 1674.003 & 264.9332 \\
\hline Lower Middle Income Countries & 1771.646 & 258.471 & 4366.076 & 1051.955 \\
\hline Upper Middle Income countries & 5821.432 & 622.7421 & 16054.49 & 3407.266 \\
\hline High Income Countries & 14564.29 & 3624.198 & 47741.91 & 7791.913 \\
\hline \multicolumn{5}{|c|}{ Education Index } \\
\hline Low income Countries & 0.340432 & 0.116000 & 0.515000 & 0.100784 \\
\hline Lower Middle Income Countries & 0.655626 & 0.404 & 0.869 & 0.120414 \\
\hline Upper Middle Income countries & 0.679289 & 0.481 & 0.842 & 0.07888 \\
\hline High Income Countries & 0.713117 & 0.475 & 0.866 & 0.07826 \\
\hline 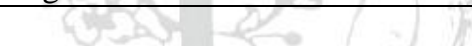 & \multicolumn{2}{|c|}{ Life expectancy index } & 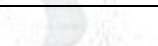 & 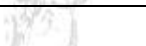 \\
\hline Low income Countries & 0.576846 & 0.386000 & 0.718000 & 0.076046 \\
\hline Lower Middle Income Countries & 0.650595 & 0.404 & 0.869 & 0.113829 \\
\hline Upper Middle Income countries & 0.800642 & 0.465 & 0.925 & 0.082549 \\
\hline High Income Countries & 0.858399 & 0.796 & 0.924 & 0.027139 \\
\hline \multicolumn{5}{|c|}{ Human Development index } \\
\hline Low income Countries & 0.423229 & 0.253000 & 0.528000 & 0.065191 \\
\hline Lower Middle Income Countries & 0.643171 & 0.407 & 0.869 & 0.117278 \\
\hline Upper Middle Income countries & 0.72992 & 0.576 & 0.832 & 0.051778 \\
\hline High Income Countries & 0.799803 & 0.704 & 0.872 & 0.035496 \\
\hline \multicolumn{5}{|c|}{ Investment on Communication (Million US\$) } \\
\hline Low income Countries & 651.1245 & 2.135000 & 6099.872 & 604.7769 \\
\hline Lower Middle Income Countries & 715.9572 & 16.94 & 7543.89 & 1205.908 \\
\hline Upper Middle Income countries & 4193.623 & 30.58 & 100215.9 & 14251.01 \\
\hline High Income Countries & 1177.243 & 28.6 & 31921.4 & 3879.955 \\
\hline \multicolumn{5}{|c|}{ Investment on Software (Million US\$) } \\
\hline Low income Countries & 554.9229 & 1.709000 & 15543.00 & 1030.914 \\
\hline Lower Middle Income Countries & 319.6095 & 5.4 & 3198.98 & 515.794 \\
\hline Upper Middle Income countries & 1152.587 & 1.2 & 23682.1 & 2422.186 \\
\hline High Income Countries & 459.7442 & 5.4 & 2896.54 & 618.3724 \\
\hline \multicolumn{5}{|c|}{ Investment on Hardware (Million US\$) } \\
\hline Low income Countries & 672.4617 & 4.937000 & 1729.947 & 449.9905 \\
\hline Lower Middle Income Countries & 699.161 & 31.7 & 12462.2 & 1441.853 \\
\hline
\end{tabular}




\begin{tabular}{|c|c|c|c|c|}
\hline Upper Middle Income countries & 2868.657 & 5.4 & 47652.6 & 7220.416 \\
\hline High Income Countries & 1070.921 & 20.5 & 4528.6 & 1231.387 \\
\hline \multicolumn{5}{|c|}{ Investment on Services (Million US\$) } \\
\hline Low income Countries & 776.9697 & 2.720000 & 12031.65 & 967.8901 \\
\hline Lower Middle Income Countries & 518.8921 & 3 & 7598.98 & 1188.299 \\
\hline Upper Middle Income countries & 2239.252 & 11.3 & 48683.5 & 6072.387 \\
\hline High Income Countries & 1010.343 & 3 & 57596.57 & 4239.413 \\
\hline \multicolumn{5}{|c|}{ Individual using Internet (\% of the population) } \\
\hline Low income Countries & 5.337253 & 0.015264 & 26.71835 & 6.523414 \\
\hline Lower Middle Income Countries & 15.70833 & 0.047023 & 76.12452 & 16.98635 \\
\hline Upper Middle Income countries & 30.31686 & 0.114097 & 80.86472 & 22.70829 \\
\hline High Income Countries & 44.90934 & 2.210692 & 98.64343 & 25.90325 \\
\hline \multicolumn{5}{|c|}{ Mobile Cellular Subscribers (per 100 people) } \\
\hline Low income Countries & 34.64806 & 0.018092 & 139.5290 & 33.87394 \\
\hline Lower Middle Income Countries & 61.73471 & 0.024533 & 164.4406 & 45.65504 \\
\hline Upper Middle Income countries & 80.32366 & 0.499948 & 180.4934 & 48.52424 \\
\hline High Income Countries & 100.4848 & 6.658398 & 210.0492 & 48.43499 \\
\hline \multicolumn{5}{|c|}{ Fixed Telephone Subscribers (per 100 people) } \\
\hline Low income Countries & 1.050174 & 0.065294 & 4.802064 & 1.082748 \\
\hline Lower Middle Income Countries & 6.787049 & 0.071725 & 29.97783 & 7.427991 \\
\hline Upper Middle Income countries & 17.43937 & 0.190299 & 48.10332 & 9.635989 \\
\hline High Income Countries & 23.02877 & 8.706189 & 43.14811 & 9.041754 \\
\hline
\end{tabular}

Mean= Mean Value, Max=Maximum, Min=Minimum, Std.Dev=Standard Deviation

\section{Description of the Variables}

HDI is consisting of three components such as living standard, education and health. GDP is used to assessed living standard of a country, literacy rate and the level of school enrollment are used to assess the educational standard and life expectancy is used for assessing the health (Kim et al., 2008). GDP per Capita which is proxy of standard of living, Education index (EI), life expectancy index (LEI) and Human Development index (HDI) are used as dependent variables, investment on ICT related components such as communication, software, hardware \& services and three controlled variable such as individual using internet, Mobile cellular subscribers and fixed telephone subscribers are used as explanatory variable. The selection of these controlled variables are taken from the previous study. It is explored that, these controlled variable has impact on the components of HDI in sub Saharan Africa (Andrés et al., 2017).

Investment on communication refer to the total spending on local and long wire line and wireless system, investment on software consisting the spending on database system, software packages and programming tools, investment on hardware refer to the spending ICT related hardware and investment on services related to amount spending on human capital, software customization and ICT related expenses (Bankole et al., 2011)

\section{Model Specification}

ARDL approach is used to explore the impact of ICT investment on the different components of HDI because some variables are stationary at level $\mathrm{I}(0)$ and some are stationary at first difference I(1). ARDL model is the most general dynamic unrestricted model in econometric literature. It handle the problems of misspecification and autocorrelation and come up with a most appropriate interpretable model (Ghouse et al., 2018). ARDL is used to explore a long-run relationship between the dependent and independent variables in small sample size (Nkoro \& Uko, 2016). The previous study used this method to investigate the 
impacts of various dimensions of ICT investment on components of human development in low, middle and high income countries (Bankole et al., 2011).

\section{Model: 1}

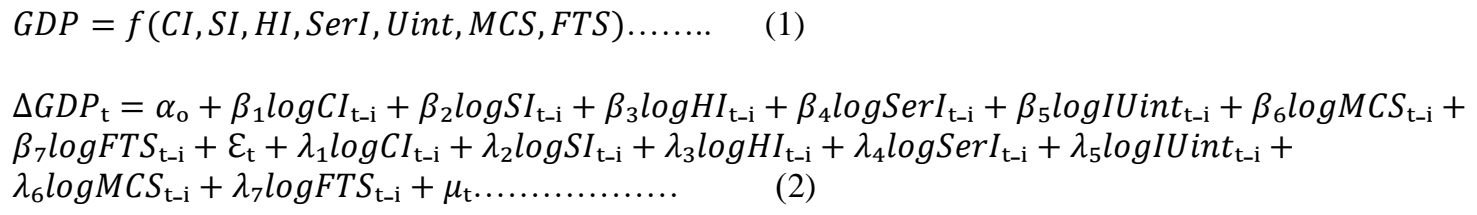

Model: 2

EInd $=f(C I, S I, H I$, SerI, IUint, MCS, FTS $) \ldots \ldots \ldots \ldots \ldots$

$\Delta E \operatorname{Ind}_{\mathrm{t}}=\alpha_{\mathrm{o}}+\beta_{1} \log C I_{\mathrm{t}-\mathrm{i}}+\beta_{2} \log S I_{\mathrm{t}-\mathrm{i}}+\beta_{3} \log H I_{\mathrm{t}-\mathrm{i}}+\beta_{4} \log \operatorname{SerI} I_{\mathrm{t}-\mathrm{i}}+\beta_{5} \log I U i n t_{\mathrm{t}-\mathrm{i}}+\beta_{6} \log M C S_{\mathrm{t}-\mathrm{i}}+$ $\beta_{7} \operatorname{logFTS} S_{\mathrm{t}-\mathrm{i}}+\varepsilon_{\mathrm{t}}+\lambda_{1} \log C I_{\mathrm{t}-\mathrm{i}}+\lambda_{2} \operatorname{logSI} I_{\mathrm{t}-\mathrm{i}}+\lambda_{3} \operatorname{logHI} I_{\mathrm{t}-\mathrm{i}}+\lambda_{4} \operatorname{logSer} I_{\mathrm{t}-\mathrm{i}}+\lambda_{5} \log \operatorname{lUint}_{\mathrm{t}-\mathrm{i}}+$ $\lambda_{6} \log M C S_{\mathrm{t}-\mathrm{i}}+\lambda_{7} \log F T S_{\mathrm{t}-\mathrm{i}}+\mu_{\mathrm{t}}$

Model: 3

$L E I=f(C I, S I, H I$, SerI, IUint, MCS , FTS $)$

$\Delta L E I_{\mathrm{t}}=\alpha_{\mathrm{o}}+\beta^{1} \log C I_{\mathrm{t}-\mathrm{i}}+\beta^{2} \log S I_{\mathrm{t}-\mathrm{i}}+\beta^{3} \log H I_{\mathrm{t}-\mathrm{i}}+\beta^{4} \log \operatorname{SerI}_{\mathrm{t}-\mathrm{i}}+\beta^{5} \log \operatorname{IUint}_{\mathrm{t}-\mathrm{i}}+\beta^{6} \log M C S_{\mathrm{t}-\mathrm{i}}+$ $\beta^{7} \log$ TTS $_{\mathrm{t}-\mathrm{i}}+\varepsilon_{\mathrm{t}}+\lambda^{1} \log C I_{\mathrm{t}-\mathrm{i}}+\lambda^{2} \log S I_{\mathrm{t}-\mathrm{i}}+\lambda^{3} \log H I_{\mathrm{t}-\mathrm{i}}+\lambda^{4} \log \operatorname{Ser} I_{\mathrm{t}-\mathrm{i}}+\lambda^{5} \log I U \operatorname{lnt}_{\mathrm{t}-\mathrm{i}}+$ $\lambda_{6} \log M C S_{\mathrm{t}-\mathrm{i}}+\lambda_{7} \log F T S_{\mathrm{t}-\mathrm{i}}+\mu_{\mathrm{t}}$.

\section{Model: 4}

$H D I=f(C I, S I, H I$, SerI, IUint $, M C S, F T S)$

$\Delta H D I_{\mathrm{t}}=\alpha_{\mathrm{o}}+\beta_{1} \log C I_{\mathrm{t}-\mathrm{i}}+\beta_{2} \log S I_{\mathrm{t}-\mathrm{i}}+\beta_{3} \log H I_{\mathrm{t}-\mathrm{i}}+\beta_{4} \operatorname{logSerI} I_{\mathrm{t}-\mathrm{i}}+\beta_{5} \log _{\log \operatorname{lnt}_{\mathrm{t}-\mathrm{i}}}+\beta_{6} \log M C S_{\mathrm{t}-\mathrm{i}}+$ $\beta_{7} \log F T S_{\mathrm{t}-\mathrm{i}}+\varepsilon_{\mathrm{t}}+\lambda_{1} \log C I_{\mathrm{t}-\mathrm{i}}+\lambda_{2} \operatorname{logSI} I_{\mathrm{t}-\mathrm{i}}+\lambda_{3} \log H I_{\mathrm{t}-\mathrm{i}}+\lambda_{4} \log \operatorname{SerI}_{\mathrm{t}-\mathrm{i}}+\lambda_{5} \log _{\operatorname{loint}} \operatorname{tin}_{\mathrm{t}-\mathrm{i}}+$

$\lambda_{6} \log M C S_{\mathrm{t}-\mathrm{i}}+\lambda_{7} \log F T S_{\mathrm{t}-\mathrm{i}}+\mu_{\mathrm{t}}$

Whereas

GDP $=$ Gross Domestic Product per Capita

$\mathrm{EI}=$ Education index

LEI $=$ Life Expectancy Index

HDI = Human Development Index

$\mathrm{CI}=$ Communication investment

SI = Software Investment

$\mathrm{HI}=$ Hardware Investment

SerI = Services Investment

IUint = Individual using internet

MCS = Mobile cellular subscribers

FTS $=$ Fixed telephone subscribers

In the first part of the above equations, $\alpha_{\mathrm{o}}$ is intercept term while $\beta_{\mathrm{i}}$ and $\varepsilon_{\mathrm{t}}$ express the short-run dynamics of model. The $2^{\text {nd }}$ part explains the long-run relationship. $H_{0}=\lambda_{1}=\lambda_{2}=\lambda_{3}=\lambda_{4}=\lambda_{5}=\lambda_{6}=\lambda_{7}=0$, it means that there is no presence of long-run relationship among the variables. 


\section{Econometric Procedure}

Following steps have been employed in the econometric procedure: (a) CSD test (b) unit root test analysis (c) cointegration test analysis (d) regression analysis.

\section{a) Cross section Dependence Test (CD)}

Cross-sectional dependence exists in panel data. It is due to the existence of common shocks, which is the parts of error term but uncorrelated with the regressors (Robertson \& Symons, 2000). To avoid these issues, it is compulsory to check the stationary and CSD. If CSD occurs, the results are unreliable and biased (H. Pesaran, 2004). In this study, three CD tests are applied to check the cross-sectional dependence such as Pesaran's (2004) CD test, Friedman's (1937) CD test, and Frees (1995) CD test (De Hoyos \& Sarafidis, 2006).

Pesaran (2004) has proposed CD test as follows:

$$
\mathrm{CD}=\sqrt{\frac{2 T}{N(N-1)}}\left(\sum_{i=1}^{N-1} \sum_{j=i+1}^{N} \hat{\rho}_{i j}\right) \sim N(0,1) i, j
$$

Whereas ${ }^{\wedge} \rho_{\mathrm{ij}}$ is residual of pairwise correlation sample, estimated by linear regression equation. The null hypotheses of no $\mathrm{CSD}, \mathrm{CD} \rightarrow \mathrm{N}(0,1)$ for $\mathrm{N}$ is relatively small and $\mathrm{T}$ is adequately large $(\mathrm{M}$. H. Pesaran, 2004).

\section{b) Friedman's test:}

Friedman (1937) suggested a nonparametric test. It is based on Spearman's rank correlation coefficient. It is computed on the basis of ranking $\left(r_{i}, 1, \ldots, r_{i s}\right)$ and its average rank is $(T+1 / 2)$ (Friedman, 1937).

$$
r_{i j}=r_{j i}=\frac{\sum_{t=1}^{T}\left\{r_{i, t}-(T+1 / 2)\right\}\left\{r_{j, t}-(T+1 / 2)\right\}}{\sum_{t=1}^{T}\left\{r_{i, t}-(T+1 / 2)\right\}^{2}}
$$

Average Spearman's correlation is given as:

$$
R_{\mathrm{ave}}=\frac{2}{N(N-1)} \sum_{i=1}^{N-1} \sum_{j=i+1}^{N} \hat{\mathrm{r}}^{2}{ }_{\mathrm{ij}}
$$

Where $r_{i j}$ is used for sample estimation of the residuals. Large values of $R_{\text {ave }}$ indicate the presence of nonzero cross-sectional correlations. The CD and $R_{\text {ave }}$ have some common features. Both tests involv in the sum of the pairwise correlation coefficients of the residual matrix rather than the sum of the squared correlations.

\section{c) Frees Test}

Frees (1995) proposed CD test to check the cross-sectional dependency in data. This statistics is based on the following equations:

$$
R_{\text {ave }}^{2}=\frac{2}{N(N-1)} \sum_{i=1}^{N-1} \sum_{j=i+1}^{N} \hat{r}_{i j}^{2}
$$




$$
\begin{aligned}
F R E=N\left\{R_{\text {ave }}^{2}-\right. & \left.(T-1)^{-1}\right\} \stackrel{d}{\rightarrow} Q \\
& =a(T)\left\{x_{1, T-1}^{2}-(T-1)\right\}+b(T)\left\{x_{2, T(T-3) / 2}^{2}-T(T-3) / 2\right\}
\end{aligned}
$$

Where $\mathrm{x}_{1, \mathrm{~T}-1}$ and $\mathrm{x}_{2}{ }_{2}, \mathrm{~T}(\mathrm{~T}-3) / 2$ are independently random variables with $\mathrm{T}-1$ and $\mathrm{T}(\mathrm{T}-3) / 2$ degrees of freedom respectively. Thus the null hypothesis is rejected if $\mathrm{R}_{\text {ave }}^{2}>(T-1)^{-1}+\mathrm{Q}_{\mathrm{q}} / \mathrm{N}$ (Frees, 1995).

\section{Panel Unit Root Tests}

After checking the CSD in data, further tests are required to check the presence of stationarity. Two types of unit root tests have been developed in panel, such as first and second generation unit root tests. The first generation test is used if the assumption follows that data is independent and identically distributed across the variables (Levin, Lin et al., 2002). It is not applicable if cross-sectional correlation occurs in the data and autoregressive parameters are considered being identical across the panel. Second generation unit root test has two tests: CIPS and CADF, being two main approaches of $2^{\text {nd }}$ generation tests. The first approach proposes non-linear instrumental variable approach to solve the problem of nuisance parameter generated due to the cross-sectional dependency (Chang et al., 2004). The 2nd approach relies on the factor structure approach (Phillips \& Sul, 2003).

The second unit root test rejected the null hypotheses that there exists no cross-sectional dependency. If cross-sectional dependence occurs in data, CIPS $2^{\text {nd }}$ generation unit root test is used in the analysis (Baltagi et al., 2007). This test encounters problem of heterogeneity. The main advantage of the test is that small number of unobserved common factors is used cross (Breitung \& Das, 2005). Pesaran (2003) suggested methodology in a CADF regression (Lewandowski, 2007). It is representing by the following formula:

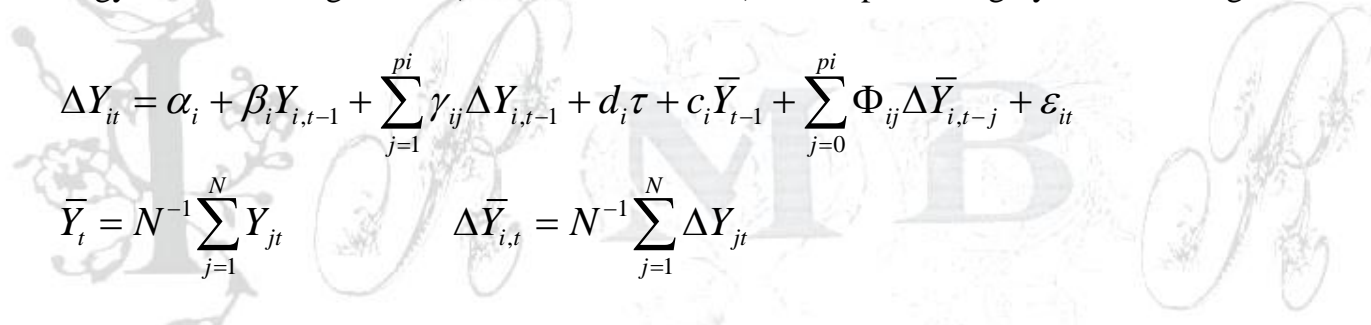

Where $e_{i t}$ is the error term. Let $\mathrm{CADF}_{\mathrm{i}}$ be the ADF measurements for the $\mathrm{i}$-th cross-sectional unit given by the t-proportion of the OLS estimates of $\beta_{\mathrm{i}}$ in the CADF regression.

\section{Long-run Cointegration Tests}

For long-run cointegration relationship among the integrated variable, three tests such as kao, Pedroni and westerlund are used. Cointegration test was originally proposed by Kao (1997) and Pedroni (1997) under the null hypothesis of no cointegration. The Kao (1997) test for cointegration is used for only homogeneous panels while Pedroni (1997) test is used for both, homogeneous as well as heterogeneous panel for testing coinetgration. Kao test used Augmented Dickey-Fuller test to estimate the cointegration among the variables. No cointegration among the variables is null hypothesis of Kao cointegration test. If null hypothesis is rejected, then cointegration exist in the panel data. ADF probability value $<0.05$ means that panel data is cointegrated (Kao, 1999). Pedroni used the Dicky-Fuller (DF) estimation and Phillips Perron test, while McCoskey used ADF estimation for unit roots (Pedroni, 1999).

\section{Regression Analysis}

ARDL model is proposed by Granger (1981), Engle \& Granger (1987) and Johansen and Juselius (1990). It is used for long-run relationship between the series of non-stationary panel data. Granger and Engle \& Granger cointegration analysis is applicable for the same integrated orders while in Johansen and Juselius 
cointegration technique is used for integrated of different orders (Granger, 1981); (Engle \& Granger, 1987); (Johansen \& Juselius, 1990); (Pesaran et al., 1999). ARDL model is very helpful to eliminate the problem of standard cointegration analysis which needs the classification of the variables of order I(0) and I(1). The pre-testing of the variables does not require in bound cointegration testing procedure included in the model for unit roots (Nkoro \& Uko, 2016). The simple ARDL model is as under:

$$
\mathrm{y}_{\mathrm{t}}=\beta_{0}+\beta_{1} \mathrm{y}_{\mathrm{t}-1}+\ldots+\beta_{\mathrm{p}} \mathrm{y}_{\mathrm{t}-\mathrm{p}}+\alpha_{0} \mathrm{x}_{\mathrm{t}}+\alpha_{1} \mathrm{x}_{\mathrm{t}-1}+\alpha_{2} \mathrm{x}_{\mathrm{t}-2}+\ldots+\alpha_{\mathrm{q}} \mathrm{x}_{\mathrm{t}-\mathrm{q}}+\varepsilon_{\mathrm{t}}
$$

Where $\varepsilon_{\mathrm{t}}$ is disturbance term. $\mathrm{y}_{\mathrm{t}}$ is lagged values of itself. $\mathrm{x}$ is explanatory variables. $\mathrm{x}_{\mathrm{t}}$ is distributed lag value.

\section{Result and Discussion}

\section{Cross-sectional Dependence (CD)}

[Table 2 and 3] explains the results of cross-sectional dependency test. The results show the presence of $\mathrm{CD}$ in the four panels of the developing countries. Pesaran CD test, Friedman CD test and Frees test were applied to check the presence of $\mathrm{CD}$ in data. These three $\mathrm{CD}$ test rejects the null hypothesis of crosssectional independence. CD test results are highly significance. Pesaran and Friedman's tests reject the null of cross-sectional independence because probability value of both is $<0.05$. Frees test also reject the null hypothesis of no cross-sectional dependence. Frees test results show that $\mathrm{T} \leq 30$, Frees' test provides the critical values for $\alpha=0.10, \alpha=0.05$ and $\alpha=0.01$ from the $Q$ distribution value. Frees statistic is larger than the critical value with at least $\alpha=0.01$ (De Hoyos \& Sarafidis, 2006).

\section{Panels}

Low.IC $=$ Low Income Countries LMIC $=$ Lower Middle Income Countries Up.MIC = Upper Middle Income Countries High.IC $=$ High income countries

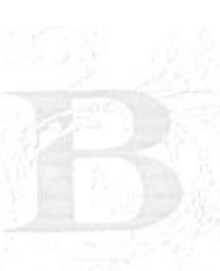

Table 2: CD test Results:

\begin{tabular}{|l|c|c|c|c|c|c|c|c|}
\hline \multirow{2}{*}{ CD Test } & \multicolumn{2}{|c|}{ Low.IC } & \multicolumn{2}{c|}{ LMIC } & \multicolumn{2}{c|}{ Up.MIC } & \multicolumn{2}{c|}{ High.IC } \\
\cline { 2 - 9 } & Test stat. & Prob. & Test stat. & Prob. & Test stat. & Prob. & Test stat. & Prob. \\
\hline Pesaran CD & 6.313 & 0.000 & 2.954 & 0.000 & 19.111 & 0.000 & 3.615 & 0.000 \\
\hline Friedman CD & 45.699 & 0.000 & 46.446 & 0.000 & 108.686 & 0.000 & 46.219 & 0.001 \\
\hline
\end{tabular}

Table 3: frees test results

\begin{tabular}{|c|c|c|c|c|}
\hline \multirow[t]{2}{*}{ CD Test } & Low.IC & LMIC & Up.MIC & High.IC \\
\hline & $\begin{array}{c}\text { Frees' cross- } \\
\text { sectional } \\
\text { independence = } \\
2.997\end{array}$ & $\begin{array}{l}\text { Frees' cross- } \\
\text { sectional } \\
\text { independence } \\
=4.872\end{array}$ & $\begin{array}{c}\text { Frees' cross- } \\
\text { sectional } \\
\text { independence }=4.519\end{array}$ & $\begin{array}{l}\text { Frees' cross-sectional } \\
\text { independence }=0.916\end{array}$ \\
\hline \multirow{4}{*}{$\begin{array}{l}\text { Frees CD } \\
\text { test }\end{array}$} & Crt. value & Crt. Value & Crt.value & Crt. value \\
\hline & $0.136^{*}$ & $0.136^{*}$ & $0.136^{*}$ & $0.136^{*}$ \\
\hline & $0.178^{* * *}$ & 0.178 ** & 0.178 ** & $0.178^{* *}$ \\
\hline & $0.260 * * *$ & $0.260 * * *$ & $0.260 * * *$ & $0.260 * * *$ \\
\hline
\end{tabular}

Crt. $=$ critical. a) Significance at $1 \%$, b) Significance at 5\%, c) Significance at $10 \%$ 


\section{Panel unit root test results:}

Table 4, 5, 6 and 7 explains unit root test analysis results. CIPS test shows mixed results at level form by using only intercept and Intercept \& trend but some variable are stationary at level and some are stationary at first difference. [Table 3] shows CIPS unit root test result at level form by using only intercept at level. GDP per Capita (log GDP) is non-stationary at level in lower middle income countries panel, life expectancy index (log LEI) is non-stationary at level in lower and lower middle income countries. Education index (log EI) is non-stationary in high income countries. Human Development Index (log HDI), software investment $(\log \mathrm{SI})$ and hardware investment $(\log \mathrm{HI})$ are non-stationary in lower middle and high income countries. Individual using internet (log I.UInt) is non-stationary in lower, lower middle and high income countries. Fixed telephone subscriber $(\log$ FTS) is non-stationary in all panels. Table 3.1 shows that all variable are stationary at first difference by using only intercept. Table 3.2 shows mixed results by using intercept \& trend at level. Mostly variables are stationary at level form in four panels.GDP per capita (log GDP) is non-stationary in upper middle income countries. Life expectancy index (log LEI) and fixed telephone subscribers (log FTS) are non-stationary in all panels. Education index (log EI) is non-stationary in lower, lower middle and high income countries. Software investment (log SI) is non-stationary in all panels except lower income countries, hardware investment (HI) is non-stationary in lower middle and high income countries while individual using internet (log I.Uint) is non- stationary in lower income countries. Table 3.4 shows that all variable are stationary at first difference by using intercept and trend. In the presence of $\mathrm{CD}$, we used kao and Pedroni test to check the cointegration among the variables in long-run (Kao, 1999).

Table 4: CIPS unit root test: Only intercept (at level):

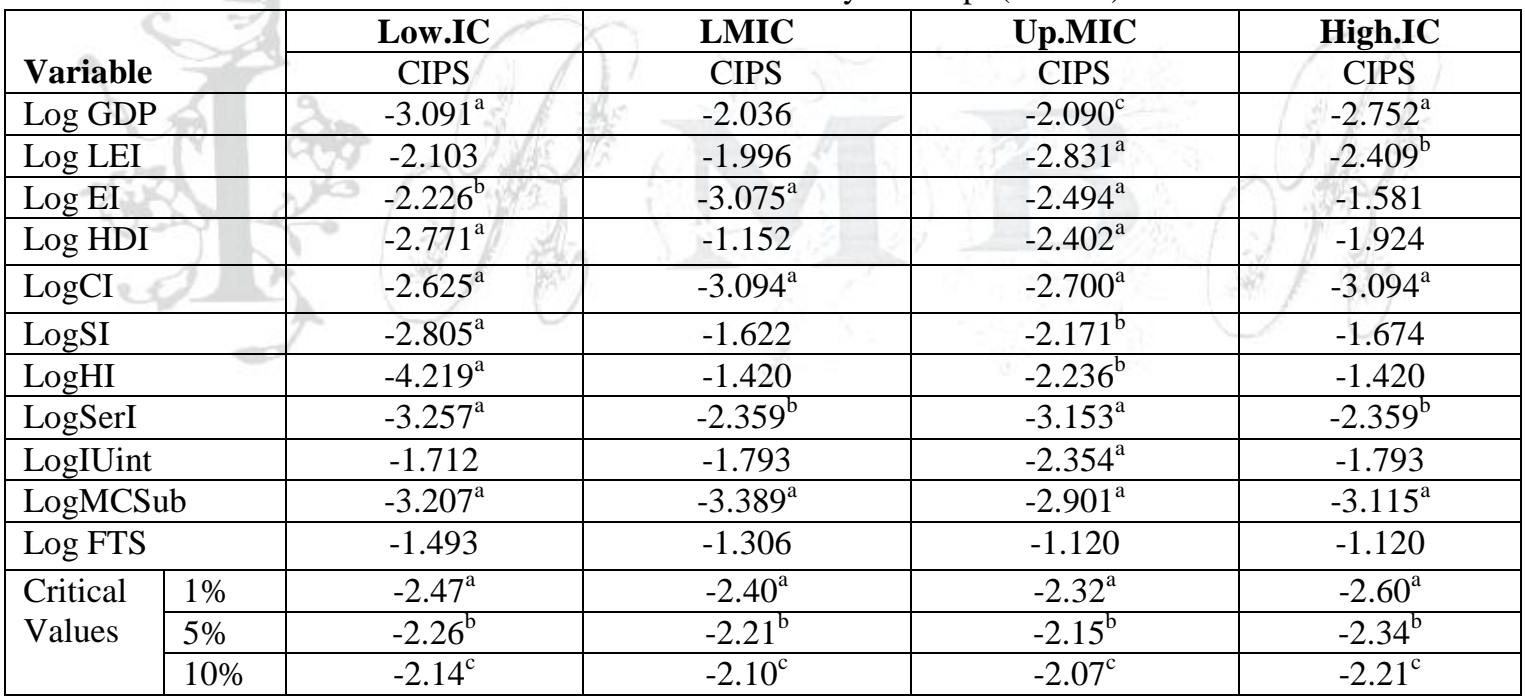

a) Significance at $1 \%$, b) Significance at 5\%,c) Significance at $10 \%$

Table 5: Case. 2 only intercept (at First Difference):

\begin{tabular}{|l|c|c|c|c|}
\hline \multirow{2}{*}{ Variable } & Low.IC & LMIC & Up.MIC & High.IC \\
\cline { 2 - 5 } & CIPS & CIPS & CIPS & CIPS $^{\mathrm{a}}$ \\
\hline Log GDP & $-4.336^{\mathrm{a}}$ & $-3.489^{\mathrm{a}}$ & $-3.258^{\mathrm{a}}$ & $-2.995^{\mathrm{a}}$ \\
\hline Log LEI & $-2.675^{\mathrm{a}}$ & $-3.305^{\mathrm{a}}$ & $-3.284^{\mathrm{a}}$ & $-4.024^{\mathrm{a}}$ \\
\hline Log EI & $-3.641^{\mathrm{a}}$ & $-4.605^{\mathrm{a}}$ & $-3.764^{\mathrm{a}}$ & $-3.171^{\mathrm{a}}$ \\
\hline Log HDI & $-4.093^{\mathrm{a}}$ & $-2.915^{\mathrm{a}}$ & $-3.538^{\mathrm{a}}$ & $-3.692^{\mathrm{a}}$ \\
\hline LogCI & $-4.750^{\mathrm{a}}$ & $-4.560^{\mathrm{a}}$ & $-4.245^{\mathrm{a}}$ & $-4.560^{\mathrm{a}}$ \\
\hline LogSI & $-4.126^{\mathrm{a}}$ & $-3.463^{\mathrm{a}}$ & $-3.824^{\mathrm{a}}$ & $-3.463^{\mathrm{a}}$ \\
\hline
\end{tabular}




\begin{tabular}{|c|c|c|c|c|c|}
\hline \multicolumn{2}{|l|}{ LogHI } & $-4.470^{\mathrm{a}}$ & $-3.819^{a}$ & $-4.662^{\mathrm{a}}$ & $-3.819^{a}$ \\
\hline \multicolumn{2}{|l|}{ LogSerI } & $-4.321^{\mathrm{a}}$ & $-3.987^{\mathrm{a}}$ & $-3.584^{\mathrm{a}}$ & $-3.987^{\mathrm{a}}$ \\
\hline \multicolumn{2}{|c|}{ LogIUint } & $-3.640^{\mathrm{a}}$ & $-4.321^{a}$ & $-3.851^{\mathrm{a}}$ & $-4.414^{a}$ \\
\hline \multicolumn{2}{|c|}{ LogMCSub } & $-4.572^{\mathrm{a}}$ & $-3.775^{\mathrm{a}}$ & $-3.709^{\mathrm{a}}$ & $-3.945^{\mathrm{a}}$ \\
\hline \multicolumn{2}{|c|}{ Log FTS } & $-3.502^{\mathrm{a}}$ & $-2.856^{\mathrm{a}}$ & $-3.416^{\mathrm{a}}$ & $-3.416^{\mathrm{a}}$ \\
\hline \multirow{3}{*}{$\begin{array}{l}\text { Critical } \\
\text { Values }\end{array}$} & $1 \%$ & $-2.47^{\mathrm{a}}$ & $-2.40^{\mathrm{a}}$ & $-2.32^{\mathrm{a}}$ & $-2.60^{\mathrm{a}}$ \\
\hline & $5 \%$ & $-2.26^{b}$ & $-2.21^{b}$ & $-2.15^{b}$ & $-2.34^{b}$ \\
\hline & $10 \%$ & $-2.14 c$ & $-2.10 c$ & $-2.07 c$ & $-2.21 c$ \\
\hline
\end{tabular}

a) Significance at $1 \%$, b) Significance at $5 \%$, c) Significance at $10 \%$

Table 6: Case. 3 intercept and trend (at level)

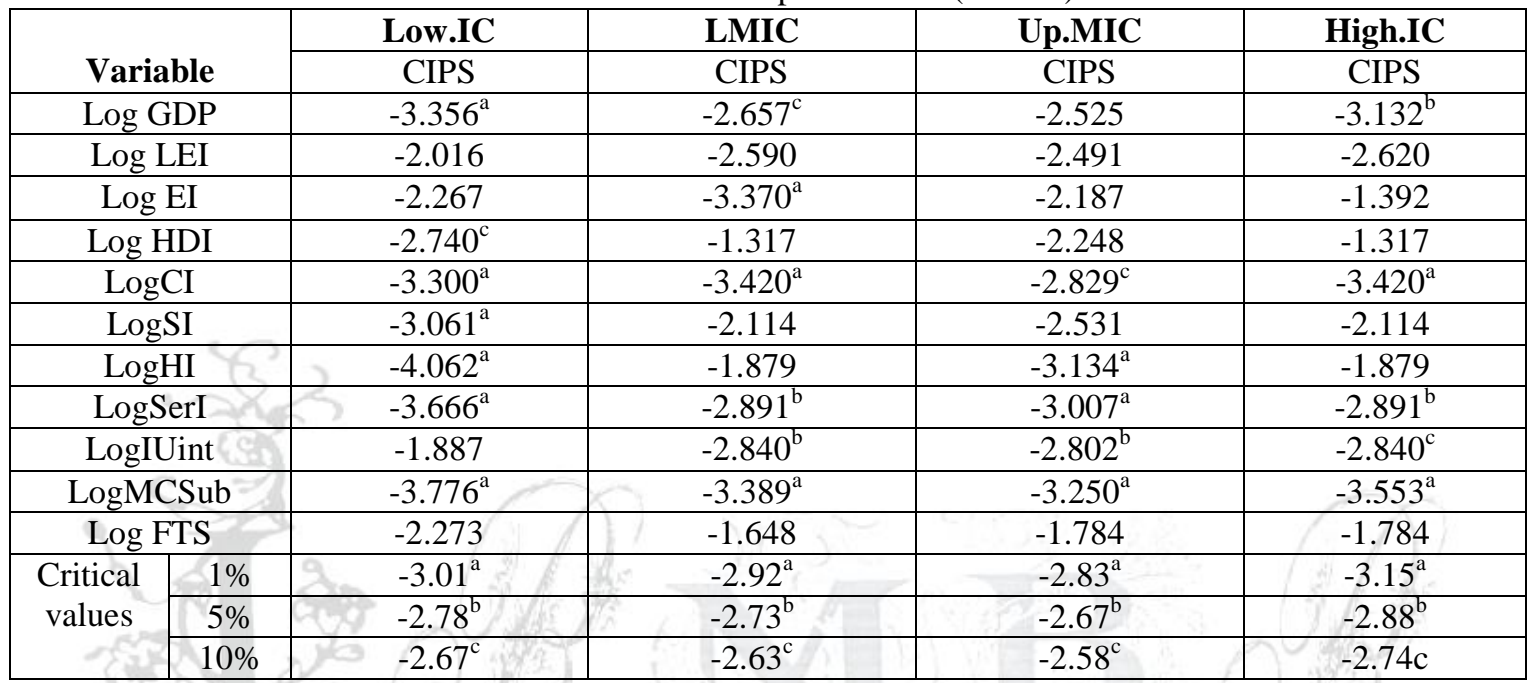

a) Significance at $1 \%$, b) Significance at $5 \%$, c) Significance at $10 \%$

Table 7: Case. 4 intercept and trend (at First Difference):

\begin{tabular}{|c|c|c|c|c|c|}
\hline \multirow{2}{*}{\multicolumn{2}{|c|}{ Variable }} & Low.IC & LMIC & Up.MIC & High.IC \\
\hline & & CIPS & CIPS & CIPS & CIPS \\
\hline \multicolumn{2}{|c|}{ LogGDP } & $-4.378^{\mathrm{a}}$ & $-3.318^{\mathrm{a}}$ & $-3.191^{\mathrm{a}}$ & $-2.464^{\mathrm{a}}$ \\
\hline \multicolumn{2}{|c|}{ LogLEI } & $-3.356^{\mathrm{a}}$ & $-3.252^{\mathrm{a}}$ & $-3.493^{\mathrm{a}}$ & $-4.211^{\mathrm{a}}$ \\
\hline \multicolumn{2}{|c|}{ LogEI } & $-3.459^{\mathrm{a}}$ & $-4.707^{\mathrm{a}}$ & $-4.159^{\mathrm{a}}$ & $-3.367^{\mathrm{a}}$ \\
\hline \multicolumn{2}{|c|}{ LogHDI } & $-4.207^{\mathrm{a}}$ & $-3.867^{\mathrm{a}}$ & $-3.857^{\mathrm{a}}$ & $-3.867^{\mathrm{a}}$ \\
\hline \multicolumn{2}{|c|}{ LogCI } & $-4.700^{\mathrm{a}}$ & $-4.526^{\mathrm{a}}$ & $-4.199^{\mathrm{a}}$ & $-4.526^{\mathrm{a}}$ \\
\hline \multicolumn{2}{|c|}{ LogSI } & $-4.431^{\mathrm{a}}$ & $-4.118^{\mathrm{a}}$ & $-4.180^{\mathrm{a}}$ & $-4.134^{\mathrm{a}}$ \\
\hline \multicolumn{2}{|c|}{ LogHI } & $-4.847^{\mathrm{a}}$ & $4.305^{\mathrm{a}}$ & $-4.307^{\mathrm{a}}$ & $-4.305^{\mathrm{a}}$ \\
\hline \multicolumn{2}{|c|}{ LogSerI } & $-4.804^{\mathrm{a}}$ & $-4.314^{\mathrm{a}}$ & $-4.248^{a}$ & $-4.314^{\mathrm{a}}$ \\
\hline \multicolumn{2}{|c|}{ LogIUint } & $-3.954^{\mathrm{a}}$ & $-4.238^{\mathrm{a}}$ & $-4.024^{\mathrm{a}}$ & $-4.238^{\mathrm{a}}$ \\
\hline \multicolumn{2}{|c|}{ LogMCSub } & $-4.645^{\mathrm{a}}$ & $-3.916^{\mathrm{a}}$ & $-3.623^{a}$ & $-3.436^{\mathrm{a}}$ \\
\hline \multicolumn{2}{|c|}{$\operatorname{logFTS}$} & $-3.572^{\mathrm{a}}$ & $-3.187^{\mathrm{a}}$ & $-3.516^{\mathrm{a}}$ & $-3.516^{\mathrm{a}}$ \\
\hline \multirow{3}{*}{$\begin{array}{l}\text { Critical } \\
\text { Values }\end{array}$} & $1 \%$ & $-3.01^{\mathrm{a}}$ & $-2.92^{\mathrm{a}}$ & $-2.83^{\mathrm{a}}$ & $-2.15^{\mathrm{a}}$ \\
\hline & $5 \%$ & $-2.78^{b}$ & $-2.73^{b}$ & $-2.67^{b}$ & $-2.88^{b}$ \\
\hline & $10 \%$ & $-2.67^{\mathrm{c}}$ & $-2.63^{c}$ & $-2.58^{\mathrm{c}}$ & $-2.74^{\mathrm{c}}$ \\
\hline
\end{tabular}

a) Significance at $1 \%$, b) Significance at 5\%, c) Significance at $10 \%$ 


\section{Panel cointegration test results:}

Table 8 shows kao test for cointegration results while table 9, 10, 11, and 12 shows Pedroni cointegration test results in lower, lower middle, upper and high income countries respectively. Results shows the presence of cointegration in four panels of developing countries. The null hypothesis that no cointegration was rejected due to significant test statistics. The long-run association established among the variables in four panels.

\section{a) Kao Test For Cointegration}

Table 8: Kao Test for Cointegration:

\begin{tabular}{|c|c|c|c|}
\hline \multicolumn{2}{|c|}{ Test } & Statistics & P-value \\
\hline Components & \multicolumn{2}{c|}{ Lower Income Countries } \\
\hline Log GDP & Augmented Dicky-Fuller t & -5.750 & 0.000 \\
\hline Log LEI & Augmented Dicky-Fuller t & -1.707 & 0.043 \\
\hline Log EI & Augmented Dicky-Fuller t & -3.074 & 0.001 \\
\hline Log HDI & Augmented Dicky-Fuller t & -2.962 & 0.001 \\
\hline \multicolumn{5}{|c|}{ Lower Middle Income Countries } \\
\hline Log GDP & Augmented Dicky-Fuller t & -4.012 & 0.000 \\
\hline Log LEI & Augmented Dicky-Fuller t & -3.988 & 0.000 \\
\hline Log EI & Augmented Dicky-Fuller t & -3.688 & 0.000 \\
\hline Log HDI & Augmented Dicky-Fuller t & -3.459 & 0.000 \\
\hline \multicolumn{5}{|c|}{ Upper Middle Income Countries } \\
\hline Log GDP & Augmented Dicky-Fuller t & -5.376 & 0.000 \\
\hline Log LEI & Augmented Dicky-Fuller t & -3.980 & 0.000 \\
\hline Log EI & Augmented Dicky-Fuller t & -4.049 & 0.000 \\
\hline Log HDI & Augmented Dicky-Fuller t & -5.965 & 0.000 \\
\hline Log GDP & Augmented Dicky-Fuller t & -3.721 & 0.000 \\
\hline Log LEI & Augmented Dicky-Fuller t & -1.865 & 0.031 \\
\hline Log EI & Augmented Dicky-Fuller t & -3.936 & 0.000 \\
\hline Log HDI & Augmented Dicky-Fuller t & -2.282 & 0.011 \\
\hline
\end{tabular}

\section{B) Pedroni test for cointegration}

Lower Income Countries

Table 9: Pedroni test for Cointegration:

\begin{tabular}{|c|c|c|c|}
\hline Components & Test & Statistic & p-value \\
\hline \multirow{3}{*}{ Log GDP } & MPP test & 5.102 & 0.000 \\
\cline { 2 - 4 } & PP test & -3.873 & 0.000 \\
\cline { 2 - 4 } & ADF test & -1.870 & 0.030 \\
\hline \multirow{2}{*}{ Log LEI } & MPP test & 4.013 & 0.000 \\
\cline { 2 - 4 } & PP test & -1.607 & 0.054 \\
\cline { 2 - 4 } & ADF test & -0.955 & 0.169 \\
\cline { 2 - 4 } & MPP test & 4.338 & 0.000 \\
\cline { 2 - 4 } & PP test & -1.090 & 0.137 \\
\hline \multirow{2}{*}{ Log HDI } & ADF test & -1.988 & 0.023 \\
\cline { 2 - 4 } & MPP test & 4.606 & 0.000 \\
\cline { 2 - 4 } & PP test & -0.494 & 0.310 \\
\cline { 2 - 4 } & ADF test & -1.328 & 0.037 \\
\hline
\end{tabular}

MPP = Modified Phillips Perron, $\mathrm{PP}=$ Phillips Perron, ADF $=$ Augmented Dicky-Fuller 
Lower Middle Income Countries

Table 10: pedroni test for Cointegration:

\begin{tabular}{|c|c|c|c|}
\hline Components & Test & Statistic & p-value \\
\hline \multirow{3}{*}{ Log GDP } & MPP test & 6.1110 & 0.000 \\
\cline { 2 - 4 } & PP test & -3.8042 & 0.000 \\
\cline { 2 - 4 } & ADF test & -1.978 & 0.032 \\
\hline \multirow{3}{*}{ Log LEI } & MPP test & 5.3025 & 0.000 \\
\cline { 2 - 4 } & PP test & -3.0537 & 0.001 \\
\cline { 2 - 4 } & ADF test & -2.3204 & 0.010 \\
\cline { 2 - 4 } & MPP test & 3.6884 & 0.000 \\
\cline { 2 - 4 } & PP test & -9.5922 & 0.000 \\
\hline \multirow{2}{*}{ Log HDI } & ADF test & -8.5266 & 0.000 \\
\cline { 2 - 4 } & MPP test & -1.1431 & 0.000 \\
\cline { 2 - 4 } & PP test & -1.6809 & 0.126 \\
\cline { 2 - 4 } & ADF test & & 0.046 \\
\hline
\end{tabular}

Upper Middle Income Countries

Table 11: Pedroni test for Cointegration:

\begin{tabular}{|c|c|c|c|}
\hline Components & Test & t-Statistic & p-value \\
\hline \multirow{2}{*}{ Log GDP } & MPP test & 6.0805 & 0.000 \\
\cline { 2 - 4 } & PP test & -1.7976 & 0.036 \\
\cline { 2 - 4 } & ADF test & -1.8470 & 0.032 \\
\hline \multirow{3}{*}{ Log LEI } & MPP test & 5.6279 & 0.000 \\
\cline { 2 - 4 } & PP test & -0.6637 & 0.253 \\
\cline { 2 - 4 } & ADF test & -2.8274 & 0.002 \\
\hline \multirow{2}{*}{ Log EI } & MPP test & 4.8458 & 0.000 \\
\cline { 2 - 4 } & PP test & -4.1610 & 0.000 \\
\cline { 2 - 4 } & ADF test & -4.3072 & 0.000 \\
\cline { 2 - 4 } & MPP test & 5.5182 & 0.000 \\
\cline { 2 - 4 } & PP test & -3.1006 & 0.001 \\
\cline { 2 - 4 } & ADF test & -2.6342 & 0.004 \\
\hline
\end{tabular}

High Income Countries

Table 12: Pedroni test for Cointegration:

\begin{tabular}{|c|c|c|c|}
\hline Components & Test & t-Statistic & p-value \\
\hline \multirow{3}{*}{ Log GDP } & MPP test & 4.0752 & 0.000 \\
\cline { 2 - 4 } & PP test & -0.8857 & 0.187 \\
\cline { 2 - 4 } & ADF test & -1.6603 & 0.048 \\
\hline \multirow{2}{*}{ Log LEI } & MPP test & 4.1194 & 0.000 \\
\cline { 2 - 4 } & PP test & 0.5779 & 0.2817 \\
\cline { 2 - 4 } & ADF test & 2.3527 & 0.004 \\
\hline \multirow{2}{*}{ Log EI } & MPP test & 3.829 & 0.000 \\
\cline { 2 - 4 } & PP test & -1.622 & 0.054 \\
\hline \multirow{2}{*}{ Log HDI } & ADF test & -1.856 & 0.014 \\
\cline { 2 - 4 } & MPP test & 3.5699 & 0.000 \\
\cline { 2 - 4 } & PP test & -2.5552 & 0.005 \\
\hline
\end{tabular}


Autoregressive-Distributed Lag (ARDL) Regression Model:

A) Dependent variable: Log GDP

Table 13: Long-run and short-run Results:

\begin{tabular}{|c|c|c|c|c|c|c|c|c|}
\hline \multirow[t]{2}{*}{ Variable } & \multicolumn{2}{|c|}{ Low.IC } & \multicolumn{2}{|c|}{ LMIC } & \multicolumn{2}{|c|}{ Up.MIC } & \multicolumn{2}{|c|}{ High.IC } \\
\hline & Coeff. & Prob. & Coeff. & Prob. & Coeff. & Prob. & Coeff. & Prob. \\
\hline \multicolumn{9}{|c|}{$\begin{array}{l}\text { Long-run Equation Results } \\
\end{array}$} \\
\hline $\log C I$ & 0.169 & 0.000 & 0.244 & 0.004 & 0.431 & 0.000 & 0.099 & 0.000 \\
\hline LogSI & 0.106 & 0.000 & 0.693 & 0.000 & 0.046 & 0.374 & 0.321 & 0.000 \\
\hline LogHI & 0.150 & 0.000 & 1.328 & 0.000 & 0.522 & 0.000 & -0.032 & 0.379 \\
\hline LogSI & -0.023 & 0.336 & 0.032 & 0.611 & -0.647 & 0.000 & 0.271 & 0.000 \\
\hline LogIUint & 0.082 & 0.000 & 0.080 & 0.029 & 0.216 & 0.001 & -0.049 & 0.487 \\
\hline LogMCS & 0.155 & 0.000 & 0.327 & 0.000 & 0.938 & 0.000 & 0.819 & 0.000 \\
\hline LogFTS & 0.055 & 0.005 & 0.265 & 0.000 & 0.479 & 0.000 & -0.178 & 0.316 \\
\hline \multicolumn{9}{|c|}{ Short-run Equation Results } \\
\hline ECM & -0.458 & 0.000 & -0.194 & 0.002 & -0.121 & 0.007 & -0.447 & 0.000 \\
\hline $\mathrm{D}(\log \mathrm{CI})$ & -0.000 & 0.993 & 0.103 & 0.069 & 0.263 & 0.000 & 0.128 & 0.032 \\
\hline $\mathrm{D}(\log \mathrm{SI})$ & 0.052 & 0.175 & -0.056 & 0.782 & 0.033 & 0.796 & 0.342 & 0.012 \\
\hline $\mathrm{D}(\log \mathrm{HI})$ & 0.007 & 0.894 & -0.299 & 0.139 & -0.081 & 0.645 & 0.245 & 0.152 \\
\hline $\mathrm{D}(\log \operatorname{SerI})$ & -0.067 & 0.042 & 0.152 & 0.166 & 0.172 & 0.055 & -0.140 & 0.117 \\
\hline $\mathrm{D}$ (LogIUint) & -0.055 & 0.296 & 0.107 & 0.000 & 0.087 & 0.159 & 0.004 & 0.955 \\
\hline $\mathrm{D}(\log M C S)$ & -0.063 & 0.393 & 0.064 & 0.232 & 0.163 & 0.028 & -0.063 & 0.587 \\
\hline $\mathrm{D}(\operatorname{LogFTS})$ & -0.027 & 0.686 & -0.164 & 0.089 & 0.290 & 0.354 & 0.186 & 0.637 \\
\hline $\mathrm{C}$ & 0.980 & 0.001 & 0.018 & 0.707 & 0.096 & 0.005 & 1.202 & 0.000 \\
\hline
\end{tabular}

a) Significance at $1 \%$, b) Significance at $5 \%$, c) Significance at $10 \%$

\section{B) Dependent variable: Log Education Index (EI)}

Table 14: Long-run Equation Results:

\begin{tabular}{|c|c|c|c|c|c|c|c|c|}
\hline \multirow[t]{2}{*}{ Variable } & \multicolumn{2}{|c|}{ Low.IC } & \multicolumn{2}{|c|}{ LMIC } & \multicolumn{2}{|c|}{ Up.MIC } & \multicolumn{2}{|c|}{ High.IC } \\
\hline & Coeff. & Prob. & Coeff. & Prob. & Coeff. & Prob. & Coeff. & Prob. \\
\hline \multicolumn{9}{|c|}{ Long-run Equation Results } \\
\hline LogCI & 0.097 & 0.000 & 0.093 & 0.016 & 0.073 & 0.000 & 0.280 & 0.000 \\
\hline LogSI & 0.045 & 0.000 & 0.086 & 0.012 & 0.031 & 0.005 & 0.242 & 0.000 \\
\hline LogHI & 0.059 & 0.001 & 0.057 & 0.000 & 0.010 & 0.034 & -0.009 & 0.602 \\
\hline LogSerI & 0.036 & 0.002 & -0.022 & 0.318 & -0.019 & 0.262 & 0.164 & 0.000 \\
\hline LogIUint & 0.005 & 0.624 & 0.027 & 0.000 & 0.059 & 0.000 & 0.066 & 0.009 \\
\hline LogMCS & 0.011 & 0.150 & 0.033 & 0.033 & -0.015 & 0.092 & 0.249 & 0.000 \\
\hline LogFTS & -0.100 & 0.000 & -0.001 & 0.271 & 0.036 & 0.003 & -0.279 & 0.542 \\
\hline \multicolumn{9}{|c|}{ Short-run Equation Results } \\
\hline ECM & -0.180 & 0.026 & -0.392 & 0.000 & -0.161 & 0.000 & -0.061 & 0.041 \\
\hline $\mathrm{D}(\log \mathrm{CI})$ & -0.021 & 0.074 & 0.006 & 0.336 & 0.011 & 0.297 & -0.039 & 0.143 \\
\hline $\mathrm{D}(\log \mathrm{SI})$ & 0.017 & 0.354 & 0.043 & 0.093 & 0.011 & 0.317 & 0.011 & 0.430 \\
\hline $\mathrm{D}(\log \mathrm{HI})$ & 0.002 & 0.765 & -0.039 & 0.118 & -0.003 & 0.806 & -0.013 & 0.510 \\
\hline $\mathrm{D}($ LogSerI $)$ & 0.007 & 0.298 & -0.018 & 0.287 & -0.005 & 0.636 & 0.000 & 0.957 \\
\hline $\mathrm{D}$ (LogIUint) & -0.004 & 0.516 & -0.000 & 0.713 & -0.019 & 0.001 & 0.017 & 0.075 \\
\hline $\mathrm{D}(\log \mathrm{MCS})$ & 0.0005 & 0.996 & 0.014 & 0.037 & -0.009 & 0.440 & -0.002 & 0.763 \\
\hline $\mathrm{D}(\operatorname{LogFTS})$ & 0.038 & 0.128 & -0.006 & 0.204 & 0.015 & 0.665 & 0.003 & 0.918 \\
\hline $\mathrm{C}$ & -0.122 & 0.045 & -0.133 & 0.000 & 0.008 & 0.014 & 0.005 & 0.231 \\
\hline
\end{tabular}

a) Significance at $1 \%$, b) Significance at $5 \%$, c) Significance at $10 \%$ 
C) Dependent variable: Log Life Expectancy Index (LEI)

Table 15: Long-run and short-run Results:

\begin{tabular}{|c|c|c|c|c|c|c|c|c|c|}
\hline \multirow{2}{*}{ Variable } & \multicolumn{2}{c|}{ Low.IC } & \multicolumn{2}{c|}{ LMIC } & \multicolumn{2}{c|}{ Up.MIC } & \multicolumn{2}{c|}{ High.IC } \\
\cline { 2 - 9 } & Coeff. & Prob. & Coeff. & Prob. & Coeff. & Prob. & Coeff. & Prob. \\
\hline \multicolumn{7}{|c|}{ Long-run equation results } \\
\hline LogCI & 0.017 & 0.000 & 0.004 & 0.310 & 0.011 & 0.000 & 0.024 & 0.000 \\
\hline LogSI & 0.022 & 0.111 & 0.066 & 0.000 & 0.009 & 0.000 & 0.001 & 0.794 \\
\hline LogHI & -0.018 & 0.261 & 0.019 & 0.006 & 0.004 & 0.095 & 0.064 & 0.002 \\
\hline LogSerI & 0.039 & 0.000 & 0.067 & 0.000 & 0.061 & 0.000 & 0.106 & 0.001 \\
\hline LogIUint & 0.034 & 0.004 & 0.081 & 0.001 & 0.024 & 0.000 & 0.086 & 0.011 \\
\hline LogMCS & -0.020 & 0.072 & 0.012 & 0.000 & 0.097 & 0.000 & 0.007 & 0.219 \\
\hline LogFTS & 0.013 & 0.125 & 0.016 & 0.000 & -0.000 & 0.362 & 0.013 & 0.295 \\
\hline \multicolumn{7}{|c|}{ Short-run equation results } & & \\
\hline ECM & -0.0137 & 0.0000 & -0.1266 & 0.0232 & -0.0774 & 0.0014 & -0.0480 & 0.0550 \\
\hline D(LogCI) & -0.0020 & 0.1209 & 0.0309 & 0.2749 & -0.0008 & 0.3891 & -0.0008 & 0.0602 \\
\hline D(LogSI) & 0.0005 & 0.6529 & -0.0032 & 0.8658 & 0.0011 & 0.5479 & 0.0019 & 0.0562 \\
\hline D(LogHI) & 0.0007 & 0.4212 & -0.0186 & 0.0048 & 0.0007 & 0.6036 & 0.0014 & 0.2637 \\
\hline D(LogSerI) & 0.0001 & 0.6278 & -0.0091 & 0.1928 & 0.0012 & 0.3421 & -0.0025 & 0.0105 \\
\hline D(LogIUint) & -0.0010 & 0.0296 & -0.0098 & 0.4074 & -0.0011 & 0.1633 & 0.0025 & 0.0404 \\
\hline D(LogMCS) & 0.0007 & 0.5211 & 0.0217 & 0.2381 & -0.0012 & 0.2889 & 0.0004 & 0.6700 \\
\hline D(LogFTS) & 0.0462 & 0.1473 & -0.0060 & 0.1950 & 0.0173 & 0.6810 & 0.0039 & 0.8375 \\
\hline D C & -0.1026 & 0.0357 & -0.0265 & 0.0184 & -0.0062 & 0.5154 & 0.0003 & 0.8348 \\
\hline
\end{tabular}

a) Significance at $1 \%$, b) Significance at $5 \%$, c) Significance at $10 \%$

\section{D) Dependent variable: Log Human Development Index (HDI)}

Table 16: Long-run and short-run Results:

\begin{tabular}{|c|c|c|c|c|c|c|c|c|}
\hline \multirow[t]{2}{*}{ Variable } & \multicolumn{2}{|c|}{ Low.IC } & \multicolumn{2}{|c|}{ LMIC } & \multicolumn{2}{|c|}{ Up.MIC } & \multicolumn{2}{|c|}{ High.IC } \\
\hline & Coeff. & Prob. & Coeff. & Prob. & Coeff. & Prob. & Coeff. & Prob. \\
\hline \multicolumn{9}{|c|}{ Long-run equation results } \\
\hline LogCI & 0.111 & 0.000 & 0.028 & 0.000 & 0.060 & 0.000 & -0.011 & 0.266 \\
\hline LogSI & 0.127 & 0.000 & 0.011 & 0.187 & -0.001 & 0.621 & 0.014 & 0.020 \\
\hline LogHI & 0.261 & 0.000 & 0.159 & 0.000 & 0.024 & 0.000 & -0.000 & 0.897 \\
\hline LogSerI & 0.022 & 0.094 & 0.028 & 0.000 & 0.046 & 0.000 & 0.012 & 0.010 \\
\hline LogIUint & 0.071 & 0.000 & 0.028 & 0.000 & 0.002 & 0.123 & 0.054 & 0.000 \\
\hline LogMCS & 0.124 & 0.000 & 0.038 & 0.000 & 0.016 & 0.000 & -0.004 & 0.584 \\
\hline LogFTS & 0.090 & 0.000 & 0.008 & 0.131 & 0.008 & 0.053 & 0.100 & 0.000 \\
\hline \multicolumn{9}{|c|}{ Short-run equation results } \\
\hline ECM & -0.0159 & 0.0593 & -0.3140 & 0.0066 & -0.2028 & 0.0015 & -0.1219 & 0.0198 \\
\hline $\mathrm{D}(\log \mathrm{CI})$ & 0.0033 & 0.4023 & 0.0454 & 0.7444 & 0.0572 & 0.5574 & -0.0050 & 0.3132 \\
\hline $\mathrm{D}(\log \mathrm{SI})$ & 0.0069 & 0.3618 & -0.0179 & 0.1172 & -0.0071 & 0.0355 & 0.0109 & 0.0219 \\
\hline $\mathrm{D}(\mathrm{Log} \mathrm{HI})$ & 0.0044 & 0.4444 & -0.0507 & 0.7136 & 0.0133 & 0.0007 & 0.0039 & 0.5018 \\
\hline $\mathrm{D}(\log$ SerI $)$ & 0.0008 & 0.8586 & 0.0684 & 0.0972 & -0.0007 & 0.8704 & -0.0032 & 0.4213 \\
\hline $\mathrm{D}$ (LogIUint) & 0.0064 & 0.1144 & 0.0168 & 0.8414 & -0.0055 & 0.3768 & 0.0008 & 0.8113 \\
\hline $\mathrm{D}(\log \mathrm{MCS})$ & 0.0117 & 0.1332 & 0.0273 & 0.5396 & -0.0027 & 0.6671 & -0.0004 & 0.9380 \\
\hline $\mathrm{D}(\mathrm{LogFTS})$ & 0.0060 & 0.6247 & -0.0211 & 0.5688 & -0.0012 & 0.8015 & 0.0137 & 0.4927 \\
\hline $\mathrm{C}$ & -0.1026 & 0.0357 & -0.0928 & 0.4243 & 0.0200 & 0.2853 & 0.1583 & 0.0618 \\
\hline
\end{tabular}

a) Significance at $1 \%$, b) Significance at $5 \%$, c) Significance at $10 \%$ 


\section{Regression Analysis}

Table 13 shows regression analysis results of the components of HDI in four panels of developing countries. Regression analysis explore the relationship between components of Human development such as standard of living (GDP), life expectancy index (LEI), Education index (EI), Human Development Index (HDI) and its selected explanatory variable such as communication investment (CI), software investment (SI), hardware investment (HI), Services investment (SerI), individual using internet (IUint), Mobile cellular subscribers (MCS) and fixed telephone subscribers (FTS) in developing countries. We investigated long-run association by applying the ARDL model proposed by Pesaran (2001) (Pesaran et al., 2001).

Table 14 explores the long and short-run relationship between the GDP and explanatory variable mentioned in the equation 3.2. The result shows that communication investment and software investment are positively significant in Low.IC, LMIC, Up.MIC and High.IC. It is found that, $1 \%$ increase in the communication investment will increase the GDP, $0.169 \%$ in Low.IC, $0.244 \%$ in LMIC, $0.431 \%$ in Up.MIC and $0.099 \%$ in High.IC. The software investment is statistically significant at $1 \%$ level of significance in Low.IC, LMIC and High.IC while insignificance in Up.MIC. The results explain that, $1 \%$ increase in software investment will increase GDP, $0.106 \%$ in lower, $0.693 \%$ in LMIC and $0.099 \%$ in High.IC. Literature shows that software has positive impact on GDP (Powell \& Dent-Micallef, 1997). The hardware investment is positively significance in lower, LMIC and Up.MIC while insignificance in High.IC. It is found that $1 \%$ in hardware investment will increase the GDP, $0.150 \%$ in lower, $1.328 \%$ in LMIC and $0.522 \%$ in Up.IC. The services investment is significance in Up.MIC but statistically negative and positively significance in High.IC at $1 \%$ level of significance. The results shows that $1 \%$ increase in services investment will increase $0.271 \%$ GDP in High.IC but decrease $0.647 \%$ GDP in Up.MIC. The previous results shows that investment in communication, software, hardware and services investment have positive and negative impact on GDP and productivity in developing countries (Kim et al., 2008) ; (Loveman, 1994); (Powell \& Dent-Micallef, 1997). The individual using internet and fixed telephone subscribers are positively significance in low.IC, LMIC and Up.MIC while insignificance in High.IC. The result shows that $1 \%$ increase in internet users will increase the $0.082 \%$ GDP in Lower, $0.080 \%$ in LMIC and $0.216 \%$ in Up.MIC. $1 \%$ increase in internet users will increase the $0.082 \%$ GDP in lower, $0.080 \%$ in LMIC and $0.216 \%$ in UP.MIC. $1 \%$ increase in fixed telephone subscribers will increase the $0.055 \%$ GDP in low.IC 0.265 , \% in LMIC and $0.479 \%$ in Up.MIC. The mobile cellular subscribers are positively significance in all panels of the developing countries. it is explore that $1 \%$ increase in mobile cellular subscribers ratio will increase GDP, $0.155 \%$ in Low.IC, $0.327 \%$ in LMIC, $0.938 \%$ Up.MIC and $0.819 \%$ in High.IC. The previous study shows that mobile phone penetration and internet penetration has positive impact on GDP (S. A. Asongu \& Nwachukwu, 2016). The short-run equation results are presented in Table 5.1. The ECM coefficient shows the percentage of yearly convergence from short to long-run equilibrium (Khan et al., 2019). The results in the current study indicates that the ECM is statistically significant and negative value, which shows that there is a cointegration relationship between the model variables. The estimated value of ECM is -0.458 involving the adjustment speed of the long-run equilibrium in response to the imbalance caused by short-run shocks in the previous period.

Table 15 explains the relationship between the Education Index (EI) and explanatory variable mentioned in the equation 4 . The result shows that investment in communication and investment in software are positively significant in all panels of the selected developing countries. The result shows that $1 \%$ increase in the communication investment will increase the education index (EI) level by $0.097 \%$ in low.IC, $0.093 \%$ in LMIC, $0.073 \%$ in Up.MIC and $0.280 \%$ in High.IC. Its shows that communication investment has more impact in high income countries as compared to panels of the developing countries. The regression results regarding software explain that, $1 \%$ increase in software investment will increase 0.045 $\%$ in Low.IC, $0.086 \%$ in LMIC and $0.031 \%$ in Up.MIC and $0.242 \%$ in High.IC. The hardware investment is significance in Low.IC, LMIC and Up.MIC. It is explored that $1 \%$ in hardware investment will increase the education index (EI) by. $059 \%$ in Low.IC, $0.057 \%$ in LMIC and $0.010 \%$ in Up.MIC. The services investment is statistically significance in Low.IC and High.IC at $1 \%$ level of significance. 
The result shows that $1 \%$ increase in services investment will increase $0.036 \%$ in EI in Low.IC and 0.164 $\%$ increase in EI in High.IC. The previous studies shows that ICT investment have positive impact on the education level in developing countries(Ngwenyama et al., 2006). The individual using internet (I.Uint) is statistically significance positively in LMIC, Up.MIC and High.IC. It is found that $1 \%$ increase in I.Uint will increase the $0.027 \%$ EI in LMIC, $0.059 \%$ in Up.MIC and $0.066 \%$ in High.IC. The mobile cellular subscribers are positively significance in LMIC and High.IC. The results shows that $1 \%$ increase in mobile cellular subscribers ratio will increase EI by $0.033 \%$ in LMIC and $0.249 \%$ in High.IC. The fixed telephone subscribers (FTS) are statistically significance in Low.IC but have negative impact on EI while in Up.MIC. FTS is positively significance. The results explore that $1 \%$ increase in FTS ratio will decrease EI by $.0100 \%$ in Low.IC and increase $0.036 \%$ EI in Up.MIC. it is found that mobile phone penetration in Sub-Sahran Africa have positive impact on education level (S. Asongu \& Nwachukwu, 2017). The shortrun model elasticity are presented in Table 5.2. The result indicates that the ECM is statistically significant and negative. The ECM coefficient value is $-0.180 \%$ which shows the percentage of yearly convergence from short to long-run equilibrium.

Table 15 explains the long-run as well as short-run relationship between the Life Expectancy Index (LEI) and explanatory variable mentioned in the equation 3.6. It is explore that communication investment (CI) is positively significant in lower, Up.MIC and High.IC while insignificant in LMIC. The results shows that 1 $\%$ increase in the CI will increase the life expectancy index (LEI) level by $0.017 \%$ in lower income, 0.011 $\%$ in Up.MIC and $0.024 \%$ in High.IC. The software investment (SI) is positively significant in LMIC and Up.MIC countries at the $1 \%$ level of significant while insignificant in lower and High.IC. The regression result shows that $1 \%$ increase in SI will increase LEI by $0.066 \%$ in LMIC and $0.009 \%$ in Up.MIC. The hardware investment (HI) is significance in High.IC at the level of $5 \%$ significance. It is explored that $1 \%$ increase in HI will increase LEI by $0.064 \%$ in High.IC. The services investment (SerI) is statistically significance in all panels of the developing countries at $1 \%$ level of significance. The results shows that 1 $\%$ increase in SerI will increase LEI by $0.03 \%$ in Low.IC and $0.067 \%$ increase in LMIC, $0.061 \%$ in Up.MIC and $0.106 \%$ in High.ICit is found that ICT investment have positive impact on health in African countries (Ngwenyama et al., 2006). The individual using internet (I.Uint) is statistically significance positively in all panels of the developing countries. It is observed that $1 \%$ increase in I.Uint will increase LEI by $0.034 \%$ in lower, $0.081 \%$ in LMIC, $0.024 \%$ in Up.MIC and $0.086 \%$ in High.IC. The mobile cellular subscribers (MCS) are positively significance in LMIC and Up.MIC. The result shows that $1 \%$ increase in MCS ratio will increase LEI by $0.012 \%$ in lower mLMIC iddle and $0.097 \%$ in Up.MIC. The fixed telephone subscribers (FTS) are statistically significance positively in LMIC at the $1 \%$ level of significance. The result explores that $1 \%$ increase in FTS ratio will increase LEI by $0.016 \%$ in LMIC. ECM result in short-run equation is statistically significant and negative. The ECM coefficient value is $0.013 \%$ at the level of $5 \%$ significance which indicates that, the percentage of yearly convergence from short to long-run equilibrium.

Table 16 explains the relationship between the Human Development Index (HDI) and explanatory variable mentioned in the equation 3.8. It is found that communication investment (CI) is positively significant in lower, LMIC and upper middle income countries while insignificant in high income countries. The result shows that $1 \%$ increase in the CI will increase HDI level by $0.111 \%$ in lower income, $0.028 \%$ in LMIC and $0.060 \%$ in Up.MIC. The software investment (SI) is positively significant in lower and Hig.IC while insignificant in LMIC and Up.MIC. The result shows that $1 \%$ increase in SI will increase HDI by 0.127 $\%$ in lower and $0.014 \%$ in High.IC. The hardware investment (HI) is significance in lower, LMIC and Up.MIC at the level of $1 \%$ significance. It is explored that $1 \%$ increase in HI will increase HDI by 0.261 $\%$ in lower income, $0.159 \%$ in LMIC and $0.024 \%$ in Up.MIC. The services investment (SerI) is statistically significance in LMIC, Up.MIC and High.IC while insignificant in lower income countries. The result shows that $1 \%$ increase in SerI will increase HDI by $0.028 \%$ in LMIC, $0.046 \%$ in Up.MIC and $0.012 \%$ in high income countries. it is explore that ICT investment have positive impact on human development (Morawczynski \& Ngwenyama, 2007); (Despotis, 2005); (Mansell, 1999). The individual using internet (I.Uint) is statistically significance positively in lower, LMIC and high income countries. It 
is found that $1 \%$ increase in I.Uint will increase HDI by $0.071 \%$ in lower, $0.281 \%$ in LMIC, $0.054 \%$ in High.IC. The mobile cellular subscribers (MCS) are positively significance in lower, LMIC and Up.MIC. The results shows that $1 \%$ increase in MCS ratio will increase HDI by $0.124 \%$ in lower, $0.038 \%$ in LMIC and $0.016 \%$ in Up.MIC. The fixed telephone subscribers (FTS) are statistically significance positively in lower, Up.MIC and high income countries. The result explores that $1 \%$ increase in FTS ratio will increase by $0.090 \%$ in lower, $0.008 \%$ Up.MIC and $0.100 \%$ high income countries. it is investigated that mobile phone, internet penetration and fixed telephone subscribers have impact on the human development in SubSaharan Africa (Asongu \& Nwachukwu, 2017). ECM is statistically significant and negative. The ECM coefficient value is $-0.015 \%$ at the level of $1 \%$ significance.

\section{Conclusions and Policy Implication:}

In the current study we focus to explore the impact of ICT investment on the components of human development. ICT investment has categorized into four segments such as communication investment, software investment, hardware investment and services investment, three control variable are added to support the model. Human development index (HDI) has divided into three components such as standard of living which is GDP, education index (EI), life expectancy index (LEI). Developing countries are divided into four panels on the basis of income such as Low.IC, LMIC, Up.MIC and High.IC. The analysis has shown that ICT investment has different impact on the components of human development into four panels of the developing countries.

The results of the current study shows that communication investments have highly significant impacts on standard living (GDP) in lower, LMIC and upper middle economies. Software investment is more effective on GDP growth in LMIC and high income countries. Hardware investment is highly significant on GDP in LMIC and Up.MIC. Services investment is highly effective on GDP in upper middle and High.IC. Individual using internet is highly significant on GDP in Up.MIC. Mobile cellular subscribers are significant on GDP across all the panels. Fixed telephone subscribers are highly significant on GDP in lower middle and Up.MIC. The regression result shows that ICT investment has more effective to increase the GDP level of the developing countries. Government should focus on ICT related field to boost up their growth. Investment on communication, software, hardware and services are highly significant on Education Index (EI) in high income countries. The results explore the High.IC have more focused on ICT related investment as compared to lower, LMIC and High.IC. It is suggested that to improve the education index level, Government should focus on ICT related investment in the developing countries. The analysis results regarding ICT related investment on Life Expectancy Index (LEI) explore that it is less effective in all panels of the developing countries. It shows that government has less focused on ICT related investment in the health sectors. To improve the level of life expectancy index, government should increase the ICT related investment in health sectors. It is also found that communication investment, software investment and hardware investment is highly effective on Human Development index (HDI) in lower and LMIC the concluding remarks of the study is that, ICT investment has impact on the components of human development including HDI in the four panel of developing countries but the significance level is different. Government of the developing countries must be focused to increase the investment on ICT to improve the GDP, EI, LEI and HDI.

\section{References}

Ahmed, E. M. (2006). ICT and human capital role in achieving knowledge-based economy: applications on Malaysia's manufacturing. Journal of Information \& Knowledge Management, 5(02), 117-128.

Ahmed, E. M. (2010). Information and communications technology effects on East Asian productivity. Journal of the Knowledge Economy, 1(3), 191-201.

Andrés, A. R., Amavilah, V., \& Asongu, S. (2017). Linkages between Formal Institutions, ICT Adoption, and inclusive human development in sub-Saharan Africa. In Catalyzing Development through ICT Adoption (pp. 175-203): Springer. 
Aristovnik, A. (2012). The impact of ICT on educational performance and its efficiency in selected EU and OECD countries: a non-parametric analysis. Available at SSRN 2187482.

Asongu, S., \& Nwachukwu, J. C. (2017). Mobile phones in the diffusion of knowledge and persistence in inclusive human development in Sub-Saharan Africa. Information Development, 33(3), 289-302.

Asongu, S. A., \& Nwachukwu, J. C. (2016). The mobile phone in the diffusion of knowledge for institutional quality in sub-Saharan Africa. World Development, 86, 133-147.

Baliamoune-Lutz, M. (2003). An analysis of the determinants and effects of ICT diffusion in developing countries. Information Technology for development, 10(3), 151-169.

Baltagi, B. H., \& Hashem Pesaran, M. (2007). Heterogeneity and cross section dependence in panel data models: theory and applications introduction. Journal of Applied Econometrics, 22(2), 229-232.

Bankole, F. O., Shirazi, F., \& Brown, I. (2011). Investigating the impact of ICT investments on human development. The Electronic Journal of Information Systems in Developing Countries, 48(1), 1-19.

Breitung, J., \& Das, S. (2005). Panel unit root tests under cross-sectional dependence. Statistica Neerlandica, 59(4), 414-433.

Chang, L.-Y., Hsia, S.-H., Wu, C.-T., Huang, Y.-C., Lin, K.-L., Fang, T.-Y., \& Lin, T.-Y. (2004). Outcome of enterovirus 71 infections with or without stage-based management: 1998 to 2002. The Pediatric infectious disease journal, 23(4), 327-332.

Chen, D. H., \& Dahlman, C. J. (2005). The knowledge economy, the KAM methodology and World Bank operations. World Bank Institute Working Paper(37256).

Chetley, A., Davies, J., Trude, B., McConnell, H., Ramirez, R., Shields, T., . . . Fereday, G. (2006). Improving health, connecting people: the role of ICTs in the health sector of developing countries-a framework paper. Retrieved from

Cortés, E. A., \& Navarro, J.-L. A. (2011). Do ICT influence economic growth and human development in European Union countries? International Advances in Economic Research, 17(1), 28-44.

De Hoyos, R. E., \& Sarafidis, V. (2006). Testing for cross-sectional dependence in panel-data models. The stata journal, 6(4), 482-496.

Despotis, D. (2005). Measuring human development via data envelopment analysis: the case of Asia and the Pacific. Omega, 33(5), 385-390.

Engle, R. F., \& Granger, C. W. (1987). Co-integration and error correction: representation, estimation, and testing. Econometrica: Journal of the econometric society, 251-276.

Erumban, A. A., \& Das, D. K. (2016). Information and communication technology and economic growth in India. Telecommunications Policy, 40(5), 412-431.

Frees, E. W. (1995). Assessing cross-sectional correlation in panel data. Journal of econometrics, 69(2), 393-414.

Friedman, M. (1937). The use of ranks to avoid the assumption of normality implicit in the analysis of variance. Journal of the american statistical association, 32(200), 675-701.

Ghouse, G., Khan, S. A., \& Rehman, A. U. (2018). ARDL model as a remedy for spurious regression: problems, performance and prospectus.

Goschin, Z., \& Constantin, D.-L. (2007). Romania's Development towards the Knowledge Economy: the ICT Dimension. Informatica Economică(3), 43.

Granger, C. W. (1981). Some properties of time series data and their use in econometric model specification. Journal of econometrics, 16(1), 121-130.

Greig, M. S., Lindsay, C., \& McQuaid, R. W. (2002). Delivering job search services in rural labour markets: the role of ICT.

Hashem, E. A. (2015). The Impact of ICT investment on Human Development. International Journal of Management Sciences, 5(1), 111-124.

Jelassi, T. (2009). ICT in Tunisia: a strategic lever for building a knowledge-based economy. The Global Information Technology Report, 2010, 153-164.

Johansen, S., \& Juselius, K. (1990). Maximum likelihood estimation and inference on cointegration-with appucations to the demand for money. Oxford Bulletin of Economics and statistics, 52(2), 169-210.

Kao, C. (1999). Spurious regression and residual-based tests for cointegration in panel data. Journal of econometrics, 90(1), 1-44. 
Khan, M. T. I., Yaseen, M. R., \& Ali, Q. (2019). Nexus between financial development, tourism, renewable energy, and greenhouse gas emission in high-income countries: A continent-wise analysis. Energy Economics, 83, 293-310.

Kim, Y. J., Kang, H., Sanders, G. L., \& Lee, S.-Y. T. (2008). Differential effects of IT investments: Complementarity and effect of GDP level. International Journal of Information Management, 28(6), 508-516.

Kozma, R. B. (2005). Monitoring and evaluation of ICT for education impact: a review. Monitoring and Evaluation of ICT in Education Projects, 19.

Kuyoro Shade, O., Awodele, O., \& Okolie Samuel, O. (2012). ICT: an effective tool in human development. International Journal of Humanities and Social Science, 2(7), 157-162.

Lee, N. (2001). Childhood and society: Growing up in an age of uncertainty: McGraw-Hill Education (UK).

Levin, A., Lin, C.-F., \& Chu, C.-S. J. (2002). Unit root tests in panel data: asymptotic and finite-sample properties. Journal of econometrics, 108(1), 1-24.

Lewandowski, P. (2007). PESCADF: Stata module to perform Pesaran's CADF panel unit root test in presence of cross section dependence.

Loveman, G. W. (1994). An assessment of the productivity impact of information technologies. Information technology and the corporation of the 1990s: Research studies, 84, 110.

Majeed, M. T., \& Ayub, T. (2018). Information and communication technology (ICT) and economic growth nexus: A comparative global analysis. Pakistan Journal of Commerce and Social Sciences (PJCSS), 12(2), 443-476.

Mansell, R. (1999). Information and communication technologies for development: assessing the potential and the risks. Telecommunications Policy, 23(1), 35-50.

Martínez-Frías, J. (2003). The importance of ICTs for developing countries. Interdisciplinary Science Reviews, 28(1), 10-14.

Morawczynski, O., \& Ngwenyama, O. (2007). Unraveling the impact of investments in ICT, education and health on development: an analysis of archival data of five West African countries using regression splines. The Electronic Journal of Information Systems in Developing Countries, 29(1), 1-15.

Neumayer, E. (2012). Human development and sustainability. Journal of Human Development and Capabilities, 13(4), 561-579.

Ngwenyama, O., Andoh-Baidoo, F. K., Bollou, F., \& Morawczynski, O. (2006). Is there a relationship between ICT, health, education and development? An empirical analysis of five West African countries from 1997-2003. The Electronic Journal of Information Systems in Developing Countries, 23(1), 1-11.

Niebel, T. (2018). ICT and economic growth-Comparing developing, emerging and developed countries. World Development, 104, 197-211.

Nkoro, E., \& Uko, A. K. (2016). Autoregressive Distributed Lag (ARDL) cointegration technique: application and interpretation. Journal of Statistical and Econometric Methods, 5(4), 63-91.

Pedroni, P. (1999). Critical values for cointegration tests in heterogeneous panels with multiple regressors. Oxford Bulletin of Economics and statistics, 61(S1), 653-670.

Pesaran, H. (2004). General diagnostic tests for cross-sectional dependence in panels. University of Cambridge, Cambridge Working Papers in Economics, 435.

Pesaran, M. H. (2004). General diagnostic tests for cross section dependence in panels.

Pesaran, M. H., Shin, Y., \& Smith, R. J. (2001). Bounds testing approaches to the analysis of level relationships. Journal of applied econometrics, 16(3), 289-326.

Pesaran, M. H., Shin, Y., \& Smith, R. P. (1999). Pooled mean group estimation of dynamic heterogeneous panels. Journal of the american statistical association, 94(446), 621-634.

Phillips, P. C., \& Sul, D. (2003). Dynamic panel estimation and homogeneity testing under cross section dependence. The Econometrics Journal, 6(1), 217-259.

Powell, T. C., \& Dent-Micallef, A. (1997). Information technology as competitive advantage: The role of human, business, and technology resources. Strategic management journal, 18(5), 375-405.

Programme, U. N. D. (2003). The Gambia Human Development Report: UNDP. 
Robertson, D., \& Symons, J. (2000). Factor residuals in SUR regressions: estimating panels allowing for cross-sectional correlation: Centre for Economic Performance, London School of Economics and Political ....

Strauss, H., \& Samkharadze, B. (2011). ICT capital and productivity growth. EIB Papers, 16(2), 8-28.

Ul Haq, M. (1995). Reflections on human development: oxford university Press.

van Ark, B., Gupta, A., \& Erumban, A. A. (2011). Measuring the contribution of ICT to economic growth. The Linked World: How ICT is Transforming Societies, Cultures and Economies. Madrid: Ariel and Fundacíon Telefonica.

Appendix

List of Countries

\begin{tabular}{|c|c|c|c|}
\hline Low income economies & $\begin{array}{c}\text { lower middle } \\
\text { income economies }\end{array}$ & $\begin{array}{c}\text { Upper middle } \\
\text { income economies }\end{array}$ & $\begin{array}{l}\text { High income } \\
\text { economies }\end{array}$ \\
\hline Benin & Bangladesh & Albania & Bahrain \\
\hline Burkina Faso & Cambodia & Algeria & $\begin{array}{c}\text { Brunei } \\
\text { Darussalam }\end{array}$ \\
\hline Ethiopia & Cameroon & Argentina & Chile \\
\hline Gambia, The & Côte d'Ivoire & Armenia & Croatia \\
\hline Guinea & Egypt, Arab Rep. & Belarus & Hungary \\
\hline Madagascar & El Salvador & Botswana & Oman \\
\hline Malawi & Ghana & Brazil & Panama \\
\hline Mali & Honduras & Bulgaria & Poland \\
\hline Mozambique & India & China & Saudi Arabia \\
\hline Niger & Indonesia & Colombia & Uruguay \\
\hline 72. Tanzania & Kenya & Costa Rica & 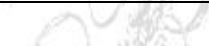 \\
\hline$\underline{\text { Togo }}$ & Moldova & Ecuador & 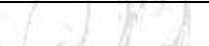 \\
\hline Uganda & Mongolia & Kazakhstan & $\sqrt{4}$ \\
\hline Yemen, Rep. & Morocco & Mauritius & +2 \\
\hline 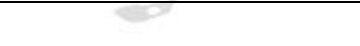 & Nicaragua & Mexico & \\
\hline & Nigeria & Paraguay & \\
\hline & Pakistan & Peru & \\
\hline & Philippines & Romania & \\
\hline & Tunisia & Russian Federation & \\
\hline & Ukraine & South Africa & \\
\hline & & Sri Lanka & \\
\hline & & Thailand & \\
\hline & & Venezuela, RB & \\
\hline
\end{tabular}

